\title{
Analisis pengaruh upah minimum provinsi, kemiskinan dan indeks pembangunan manusia terhadap tingkat partisipasi angkatan kerja di Provinsi Jambi
}

\author{
Faruq Kukuh Wasono*; Erfit ; Erni Achmad \\ Prodi Ekonomi Pembangunan Fak.Ekonomi dan Bisnis Universitas Jambi \\ *E-mail korespondensi: faruqkukuh347@gmail.com
}

\begin{abstract}
This study aims to analyze the development of labor force participation rate in Jambi province, minimum wages, poverty, and human development index in and to analyze the influence of minimum wage, poverty, and human development index on labor force participation rate in Jambi province from 2002 to 2017 using multiple linear regression tools and the analysis method used is a descriptive and quantitative analysis using secondary data. based on the results of the study showed the development of the provincial minimum wage has increased every year, while poverty, human development index, and labor force participation rate in Jambi province fluctuated from 2002 -2017. and based on the test results simultaneously the minimum wage province, human development index poverty has a significant effect on the level of labor participation in Jambi province, while the partial test results are known that the minimum wage variable of the human development index has a negative and significant effect on the labor force participation rate in Jambi province.
\end{abstract}

Keywords : Labor for participation rate, provincial minimum wage, pover, Human development index

\begin{abstract}
Abstrak
Penelitian ini bertujuan untuk menganalisis perkembangan tingkat partisipasi angkatan kerja di provinsi Jambi, upah minimum, tingkat kemiskinan dan indeks pembangunan manusia di provinsi Jambi dan untuk menganalisis pengaruh upah minimum, tingkat kemiskinan dan indeks pembangunan manusia terhadap tingkat partisipasi angkatan kerja di provinsi Jambi periode tahun 2002-2017 dengan menggunakan alat regresi linear berganda. metode analisis yang digunakan adalah analisis deskriptif dan kuantitatif dengan menggunakan data sekunder. berdasarkan perkembangannya upah minimum provinsi mengalami peningkatan setiap tahunnya, sedangkan tingkat kemiskinan, indeks pembangunan manusia dan tingkat partisipasi angkatan kerja di provinsi Jambi mengalami fluktuasi dari tahun ke tahun. Berdasarkan hasil uji secara simultan upah minimum provinsi, kemiskinan, dan indeks pembangunan manusia berpengaruh terhadap tingkat partisipasi angkatan kerja di provinsi Jambi, Sedangkan hasil uji parsial diketahui bahwa variabel upah minimum dan IPM berpengaruh negatif dan signifikan terhadap tingkat partisipasi angkatan kerja di provinsi Jambi.
\end{abstract}

Kata kunci: Tingkat partisipasi angkatan kerja, Upah minimum, Kemiskinan, Indeks pembangunan manusia. 


\section{PENDAHULUAN}

Perluasan penyerapan tenaga kerja diperlukan untuk mengimbangi laju pertumbuhan penduduk usia muda yang masuk ke pasar tenaga kerja. Ketidakseimbangan antara pertumbuhan angkatan kerja dan penciptaan lapangan kerja akan menyebabkan tingginya angka pengangguran. Kemudian, meningkatnya angka pengangguran akan mengakibatkan pemborosan sumber daya dan potensi angkatan kerja yang ada, meningkatnya beban masyarakat, merupakan sumber utama kemiskinan dan mendorong terjadinya peningkatan keresahan sosial, serta menghambat pembangunan ekonomi jangka Panjang (Depnakertrans, 2004). Setiap pembangunan ekonomi daerah mempunyai tujuan utama untuk meningkatkan jumlah dan jenis peluang kerja untuk masyarakat daerah, dalam upaya untuk mencapai tujuan tersebut pemerintah daerah dan masyarakat harusnya secara bersama-sama mengambil inisiatif pembangunan daerah. Oleh karna itu, pemerintah daerah beserta partisipasi masyarakatnya dan dengan sumber daya yang ada harus mampu menafsirkan potensi sumber daya yang diperlukan untuk merancang dan membangun perekonomian daerah (Arsyad,2004).

Menurut kusumosuwido (1981), kegiatan ekonomi harus tumbuh dan berkembang lebih cepat dari pertambahan jumlah orang mencari pekerjaan. Keadaan ini sangat diperlukan untuk memperkecil tingkat pengangguran terbuka. Data Tingkat partisipasi angkatan kerja di Provinsi Jambi pada tahun 2010 adalah sebesar 66,38\%, meningkat pada tahun 2011 sebesar 67,67\% menurun pada tahun 2012 menjadi 65,07\%, kemudian pada tahun 2013 kembali menurun menjadi 62,66\%, peningkatan terjadi pada tahun 2014 dan 2015, dari 65,59\% ditahun 2014 menjadi 66,14\% ditahun 2015. Sedangkan pada tahun 2016 dan 2017 sebesar 67,54\% dan 67,52\%. Tingkat partisipasi angkatan kerja yang tertinggi terjadi pada tahun 2011, dimana Tingkat partisipasi angkatan kerja di provinsi jambi sebesar 67,67\% dan terendah terjadi pada tahun 2013 sebesar 62,66\%. (Badan Pusat Statistik Provinsi Jambi, 2019).

Laju pertumbuhan jumlah penduduk harus sejalan dengan perluasan tenaga kerja yang ada. tercatat jumlah penduduk di Provinsi Jambi terus mengalami peningkatan dimana pada tahun 2010 jumlah penduduk Provinsi Jambi berjumlah 3.092.265 jiwa kemudian di tahun 2011 terjadi peningkatan menjadi 3.169.814 jiwa di tahun 2012 sebesar 3.169.814 jiwa, tahun 2013 meningkat sebesar 3.317.034 jiwa, pada tahun 2014 jumlah penduduk mencapai 3.344.421 jiwa, kemudian ditahun 2015 meningkat menjadi 3.402.052 jiwa, selanjutnya terus meningkat ditahun berikutnya yaitu 3.458.926 jiwa ditahun 2016 menjadi 3.515.017 jiwa ditahun 2017. Perluasan lapangan pekerjaan diharapkan dapat mensejahtrakan masyarakat. Untuk itu pendapatan harus sesuai dengan upah minimum yang ditetapkan di setiap masing-masing pemerintah daerah. Upah minimum provinsi dapat mengukur tingkat kesejahtraan masyarakat di suatu wilayah. Di Provinsi Jambi upah minimum provinsi selalu naik setiap tahunnya, pada tahun 2010 UMP Provinsi Jambi sebesar Rp.900.000, di tahun 2011 UMP naik sebesar Rp. 1.028.000, pada tahun 2012 naik menjadi Rp.1.142.500 di tahun 2013 kembali naik menjadi Rp. 1.300.000, dan seterusnya naik di tahun berikutnya sebesar Rp. 1.502.230 ditahun 2014 dan Rp. 1.710.000 ditahun 2015, tahun 2016 sebesar Rp. 1.906 .650 dan pada tahun 2017 Rp.2.063.948 ini menunjukkan bahwa dengan meningkatnya upah minimum provinsi maka semakin sejahtera masyarakat di daerah tersebut. Upah minimum provinsi pada tahun 2010 sebesar Rp.900.000 dan pada tahun 2017 sebesar Rp.2.063.948, dalam kurun waktu 8 tahun upah minimum provinsi kenaikannya sebesar Rp.1.163.948 dari tahun 2010-2017. (Badan Pusat Statistik Provinsi Jambi, 2019). 
Dalam mengurangi masalah ketenagakerjaan yang dihadapi negara berkembang perlu adanya solusi yaitu memberikan upah yang memadai dan menyediakan kesempatan kerja bagi kelompok masyarakat miskin. Oleh karna itu, peningkatan kesempatan kerja merupakan unsur yang paling esensial dalam setiap strategi pembangunan yang menitik beratkan kepada penghapusan (Arsyad, 1999). Persentase kemiskinan di Provinsi Jambi cendrung berada di angka 8\%, dimana persentase kemiskinan di Provinsi Jambi pada tahun 2010 sebesar 8,40\% tahun 2011 sebesar 7,9\%, ditahun 2012 naik menjadi 8,41\%, tingkat kemiskinan dijambi terus mengalami peningkatan setiap tahunnya, pada tahun 2013 tingkat kemiskinan sebesar 8,41\%, ditahun berikutnya naik menjadi 8,39\% ditahun 2014, dan kembali naik pada tahun tahun 2015 menjadi 8,86\% sedangkan pada tahun 2016 dan 2017 terjadi penurunan dari 8,41\% menjadi 8,19\%. Sedangkan tingkat kemiskinan tertinggi terjadi di tahun 2015 sebesar 8,86\%, dan terendah 7,9\% ditahun 2011 (Badan Pusat Statistik Provinsi Jambi, 2019).

Selain itu Indeks pembangunan manusia di provinsi jambi terus mengalami peningkatan setiap tahunnya, Indeks Pembangunan Manusia di Provinsi Jambi pada tahun 2010 adalah sebesar 65,39\%, tahun 2011 sebesar 66,14\%, kemudian di tahun 2012 Indeks Pembangunan Manusia di Provinsi Jambi naik sebesar 66,94\%, kemudian ditahun berikutnya Indeks Pembangunan Manusia di Provinsi Jambi terus mengalami peningkatan dimana pada tahun 2013 sebesar 67,76\%, ditahun 2014 sebesar 68,24\% dan kembali meningkat ditahun 2015 menjadi 68,69\% begitu juga pada tahun 2016 naik menjadi 69,62\% menjadi 69,99\% ditahun 2017. Sedangkan Indeks Pembangunan Manusia di Provinsi Jambi yang terendah terjadi pada tahun 2010 yaitu sebesar 65,39\%. karena setiap tahunnya Indeks Pembangunan Manusia selalu meningkat maka yang tertinggi terjadi pada tahun 2017 sebesar 69,99\%. (Badan Pusat Statistik Provinsi Jambi, 2019).

Dari uraian di atas maka penulis tertarik menganalisis sejauh mana pengaruh Upah Minimum, Kemiskinan, dan Indeks Pembangunan Manusia terhadap Tingkat Partisipasi Angkatan Kerja di Provinsi Jambi periode tahun 2002-2017. Berdasarkan hal tersebut penulis mengangkat judul "Analisis pengaruh upah minimum provinsi, kemiskinan, dan indeks pembangunan manusia terhadap tingkat partisipasi angkatan kerja di Provinsi Jambi".

\section{METODE}

Metode penelitian yang digunakan dalam penelitian ini adalah metode analisis deskriptif untuk melihat serta menganalisis perkembangan-perkembangan yang terjadi dan metode analisis kuantitatif untuk melihat pengaruh variabel-variabel bebas terhadap variabel terikat, dengan data yang digunakan ialah data sekunder (time series) selama 16 tahun yaitu dari tahun 2002 hingga 2017. Adapun variabel-variabel yang digunakan dalam penelitian ini sebagai variabel bebas (independent) yaitu Upah Minimum, Tingkat Kemiskinan dan Indeks pembangunan Manusia. Sedangkan variabel terikat (dependent) ialah Tingkat Partisipasi Angkatan kerja.

Untuk menjawab rumusan masalah yang pertama mengenai perkembangan tingkat partisipasi angkatan kerja, upah minimum provinsi, kemiskinan dan indeks pembangunan manusia di Provinsi Jambi, digunakan rumus berikut :

$$
Y=\frac{X_{1}-X_{0}}{X_{0}} \times 100 \%
$$


Dimana : $\quad \mathrm{Y} \quad=$ Perkembangan UMP, Kemiskinan, IPM dan TPAK

$\mathrm{X}_{1} \quad=$ UMP, Kemiskinan, IPM dan TPAK tahun tertentu

$\mathrm{X}_{0} \quad=\mathrm{UMP}$, Kemiskinan, IPM dan TPAK tahun sebelumnya

Untuk mengetahui pengaruh upah minimum provinsi, kemiskinan, dan indeks pembangunan manusia (IPM) terhadap tingkat partisipasi angkatan kerja di Provinsi Jambi dengan menggunakan regresi linear berganda, dengan rumus sebagai berikut:

$$
Y=\beta_{\circ}+\beta_{1} X_{1}+\beta_{2} X_{2}+\beta_{3} X_{3}+e
$$

Persamaan tersebut kemudian ditransformasikan ke dalam fungsi persamaan sebagai berikut:

Dimana:

$$
T P A K=\beta_{\circ}+\beta_{1} U M P_{1}+\beta_{2} T K M_{2}+\beta_{3} I P M_{3}+e
$$

$\mathrm{Y} \quad=$ Tingkat partisipasi angkatan kerja

Bo $\quad=$ Konstanta persamaan regresi

$\beta_{1} \beta_{2} \beta_{3} \quad=$ Koefisien regresi masing-masing variabel

$\mathrm{X} 1=$ Upah minimum provinsi

$\mathrm{X} 2=$ Tingkat kemiskinan

X3 = Indeks pembangunan manusia

$\mathrm{e} \quad=$ Standar error

\section{Uji hipotesis}

\section{Uji F statistik}

Uji F digunakan untuk menguji signifikansi koefisien regresi secara bersama atau dilakukan dengan mengetahui ada atau tidaknya pengaruh seluruh variabel bebas terhadap variabel terikat atau pengujian secara serentak.

\section{Uji t statistik}

Uji ini digunakan untuk mengetahui secara parsial seberapa besar pengaruh tingkat signifikansi variabel bebas (independen) terhadap variabel terikat (dependen).

\section{Koefisien determinasi (R-square)}

Analisis determinasi dalam regresi linear berganda digunakan untuk mengetahui persentase sumbangan pengaruh variabel independent terhadap variabel dependen, maka digunakan joefisien determinasi dimana rumusnya sebagai berikut :

Dimana :

$$
R^{2}=\frac{\sum(Y i-Y)^{2}}{\sum(Y i-Y)^{2}}
$$

$\sum(\mathrm{Yi}-\mathrm{Y})^{2} \quad$ : jumlah kuadrat total yang merupakan total variasi $\mathrm{Y}$

$\sum(Y i-Y)^{2} \quad:$ jumlah kuadrat regresi yang merupakan total variasi yang dapat dijelaskan oleh garis regresi

\section{Uji asumsi klasik}

\section{Uji normalitas}

Uji normalitas bertujuan apakah model regresi variabel dependen dan variabel independen mempunyai kontribusi atau tidak. Model regresi yang baik adalah data distribusi normal atau mendekati normal (Ghozali,2012). 


\section{Uji multikolinearitas}

Multikolinearitas bertujuan menguji apakah model regresi ditemukan korelasi diantara variabel antara variabel independen, jika terjadi korelasi maka pada model tersebut terdapat problem multikolinearitas (sumodiningrat,1994). Untuk mendeteksi ada atau tidak adanya multikolinearitas dengan melihat nilai tolerance dan VIF. Semakin kecil nilai tolerance dan semakin besar VIF maka semakin mendekati masalah multikolinearitas, jika tolerance lebih dari 0,1 dan VIF kurang dari 10 maka tidak ada masalah multikolinearitas.

\section{Uji heteroskedastisitas}

Menurut Gozali (2005), uji heterokedastisitas bertujuan untuk menguji apakah dalam model regresi terjadi ketidaksamaan varians dari residual satu penelitian ke penelitian yang lain. Menurut sumodiningrat (2001), jika varians dari residual satu penelitian ke penelitian yang lain tetap, maka disebut heterokedastisitas atau tidak mengandung heterokedastisitas. Dasar mendeteksi heterokedastisitas adalah jika nilai obs*R-Squared $<X^{2}$ tabel berarti tidak ada masalah heterokedastisitas, sebaliknya jika lebih besar maka terdapat heterokedastisitas.

\section{Uji autokorelasi}

Menurut Ghozali 2012), Autokorelasi bertujuan menguji apakah dalam model regresi ada korelasi antara kesalahan pengganggu pada periode-t dengan kesalahan pengganggu pada periode t-1 (sebelumnya). Pengujian auto korelasi dilakukan dengan uji durbin watson dengan membandingkan nilai durbin watson hitung (d) dengan nilai durbin watson tabel, yaitu batas atas (du) dan batas bawah (dl).

\section{HASIL DAN PEMBAHASAN}

\section{Perkembangan upah minimum Provinsi Jambi}

Kebijakan Upah Minimum di Indonesia tertuang dalam Peraturan Menteri Tenaga Kerja Nomor : per01/Men/1999 tentang upah minimum adalah upah bulanan terendah yang terdiri dari upah pokok termasuk tunjangan tetap. Yang dimaksud dengan tunjangan tetap adalah suatu jumlah imbalan yang diterima pekerja secara tetap dan teratur pembayarannya, yang tidak dikaitkann dengan kehadiran ataupun pencapiian potensi tertentu dan UU ketenagakerjaan No 13 tahun 2003. Yang isinya bahwa semua pekerja baik yang berstatus tetap maupun tidak tetap, serta yang masih dalam masa percobaan harus di bayar dengan layak berdasarkan Upah Minimum Regional (UMR). Demi menjaga kestabilan perekonomian tingkat upah biasanya memiliki standart yang telah ditetapkan oleh pemerintah.

Penetapan upah setiap tahunnya ditetapkan melalui proses yang panjang. Dewan Pengupahan Daerah (DPD) yang terdiri dari birokrat, akademisi, buruh dan pengusaha mengadakan rapat untuk membentuk tim survei yang secara langsung turun mencari tahu harga sejumlah kebutuhan yang dibutuhkan oleh pegawai, karyawan dan buruh. Survei dilakukan disejumlah kota dalam provinsi tersebut yang di anggap representatif atau mewakili. Di perolehlah Angka Kebutuhan Hidup Layak (KHL), berdasarkan KHL tersebut, DPD mengusulkan Upah Minimum Regional (UMR) kepada Gubenur untuk disahkan melalui mekanisme dengan melihat inflasi dan pertumbuhan ekonomi yang ada dimasing-masing provinsi sehingga tiap-tiap provinsi memiliki jumlah Upah Minimum Provinsi yang berbeda-beda. 
Tabel 1. Perkembangan upah minimum di Provinsi Jambi tahun 2002-2017.

\begin{tabular}{ccc}
\hline Tahun & Upah Minimum Provinsi (Rp) & Perkembangan (\%) \\
\hline 2002 & Rp. $304.000,00$ & - \\
2003 & Rp. $390.000,00$ & 28,29 \\
2004 & Rp. $425.000,00$ & 8,97 \\
2005 & Rp. $485.000,00$ & 14,12 \\
2006 & Rp. $563.000,00$ & 16,08 \\
2007 & Rp. $658.000,00$ & 16,87 \\
2008 & Rp. $724.000,00$ & 10,03 \\
2009 & Rp. $800.000,00$ & 10,49 \\
2010 & Rp. $900.000,00$ & 12,50 \\
2011 & Rp. $1.028 .000,00$ & 14,22 \\
2012 & Rp. $1.142 .500,00$ & 11,14 \\
2013 & Rp. $1.300 .000,00$ & 13,79 \\
2014 & Rp. $1.502 .230,00$ & 15,56 \\
2015 & Rp. $1.710 .000,00$ & 13,83 \\
2016 & Rp. $1.906 .650,00$ & 11,50 \\
2017 & Rp. $2.063 .948,00$ & 8,25 \\
\hline Rata-rata & & $\mathbf{1 4 , 1 0}$ \\
\hline
\end{tabular}

Sumber: Badan Pusat Statistik Provinsi Jambi,2019(diolah)

Berdasarkan Tabel 1 dapat diketahui perkembangan Upah Minimum di Provinsi Jambi tahun 2002-2017. Selama kurun waktu 16 tahun terakhir rata-rata perkembangan Upah Minimum Provinsi Jambi adalah sebesar 14,10 persen. Dan perkembangan Upah Minimum Provinsi yang tertinggi terjadi pada tahun 2003 yaitu sebesar 28,29 persen sedangkan perkembangan terendah terjadi pada tahun 2017 sebesar 8,25 persen. Jika dibandingkan dengan UMP Provinsi- Provinsi di Indonesia pada tahun 2017, dimana Upah Minimum Provinsi di indonesia yang tertinggi yaitu Provinsi DKI Jakarta dengan UMP sebesar Rp.3.355.750 dan Upah Minimum Provinsi terendah adalah Provinsi Daerah Istimewa Yogyakarta yaitu sebesar Rp.1.337.645, sedangkan UMP Provinsi Jambi berada pada urutan 14 dari 34 provinsi yang ada di Indonesia. Untuk di pulau Sumatera Upah Minimum Provinsi tertinggi yaitu Provinsi Nangroe Aceh Darussalam sebesar Rp.2.500.000 dan terendah yaitu provinsi Bengkulu sebesar Rp.1.730.000, dan jika diurutkan UMP di pulau Sumatera, Provinsi Jambi berada diurutan ke 6 dari 10 provinsi yang ada dipulau sumatera.

\section{Perkembangan tingkat kemiskinan di Provinsi Jambi}

Tingkat kemiskinan di Provinsi Jambi jika dilihat dari tabel dibawah cenderung mengalami penurunan. Berdasarkan Tabel 2 dapat diketahui perkembangan Tingkat Kemiskinan di Provinsi Jambi tahun 2002-2017. Dalam kurun waktu 16 tahun rata-rata Tingkat Kemiskinan di Provinsi Jambi sebesar 9,78 persen dan rata-rata perkembangan Tingkat Kemiskinan provinsi Jambi adalah sebesar $-2,98$ persen. Dan Tingkat Kemiskinan tertinggi terjadi pada tahun 2002 yaitu 13,18 persen dan terendah terjadi pada tahun 2011 yaitu 7,9 persen. Dari tahun 2002-2017. Tingkat Kemiskinan cenderung mengalami penurunan lalu stabil diangka 8 persen. Kemiskinan di Provinsi Jambi yang 
terjadi paling tinggi terdapat di Kabupaten Tanjung Jabung timur dengan tingkat kemiskinan sebesar 12.58 persen yaitu pada tahun 2017. Sedangkan pada Kota Sungai Penuh tingkat Kemiskinan yang terjadi hanya 2.78 persen pada tahun 2017 dan merupakan tingkat kemiskinan terendah di Provinsi Jambi. Untuk mengetahui keadaan Tingkat Kemiskinan di Provinsi Jambi dapat dilihat pada tabel sebagai berikut :

Tabel 2. Tingkat kemiskinan Provinsi Jambi tahun 2002-2017.

\begin{tabular}{ccc}
\hline Tahun & Tingkat Kemiskinan & Perkembangan $(\boldsymbol{\%})$ \\
\hline 2002 & 13,18 & - \\
2003 & 12,74 & $-3,34$ \\
2004 & 12,45 & $-1,33$ \\
2005 & 11,88 & $-4,57$ \\
2006 & 11,37 & $-4,29$ \\
2007 & 10,27 & $-9,67$ \\
2008 & 9,28 & $-9,63$ \\
2009 & 8,55 & $-7,86$ \\
2010 & 8,40 & $-1,75$ \\
2011 & 7,90 & $-5,95$ \\
2012 & 8,28 & 4,81 \\
2013 & 8,41 & 1,57 \\
2014 & 8,39 & $-0,23$ \\
2015 & 8,86 & 5,60 \\
2016 & 8,41 & $-5,07$ \\
2017 & 8,19 & $-2,61$ \\
\hline Rata-rata & & $-2,98$ \\
\hline
\end{tabular}

Sumber: Badan Pusat Statistik Provinsi Jambi,2019(diolah)

\section{Perkembangan indeks pembangunan manusia di Provinsi Jambi}

Indek Pembangunan Manusia merupakan indikator strategis yang banyak digunakan untuk melihat upaya dalam kinerja pembangunan secara meyeluruh disuatu wilayah. Indeks pembangunan manusia menggambarkan hasil dari program pembangunan yang telah dilakukan beberapa tahun sebelumnya. Terdapat 3 komponen indeks pembangunan manusia yang mempengaruhi perkembangan Indeks pembangunan manusia, komponen-komponen IPM itu meliputi angka harapan hidup, angka melek huruf dan rata-rata lama sekolah. Nilai indeks pembangunan manusia provinsi jambi dan perkembangannya dapat dilihat pada tabel dibawah ini :

Berdasarkan Tabel 3 diperoleh bahwa Indeks Pembangunan Manusia di Provinsi Jambi mengalami kenaikan dan penurunan selama periode 2002-2017. Indeks Pembangunan Manusia Provinsi Jambi mengalami rata-rata peningkatan sebesar 0,11 persen dalam kurun waktu 16 tahun. Peningkatan tertinggi terjadi pada tahun 2012 yaitu sebesar 1,41 persen, kenaikan ini terjadi diduga karena meningkatnya lonjakan nilai ratarata lama sekolah dikuti dengan naiknya angka harapan hidup serta pendapatan perkapita masyarakat pada tahun 2012, sedangkan penurunan terendah terjadi pada tahun 2014 sebesar -2,69 persen, yang diduga penurunan terjadi karena turunnya pendapatan perkapita masyarakat pada tahun tersebut. Jika dibandingkan dengan dengan tingkat Indeks Pembangunan Manusia Provinsi lain di Indonesia, Provinsi Jambi menempati urutan ke 16 dari 34 provinsi di Indonesia pada tahun 2017. 
Tabel 3. Perkembangan indeks pembangunan manusia Provinsi Jambi

\begin{tabular}{ccc}
\hline Tahun & Indeks Pembangunan Manusia & Perkembangan $(\boldsymbol{\%})$ \\
\hline 2002 & 68.80 & - \\
2003 & 69.75 & 1,38 \\
2004 & 70.10 & 0,50 \\
2005 & 71.00 & 1,28 \\
2006 & 71.30 & 0,42 \\
2007 & 71.46 & 0,22 \\
2008 & 71.99 & 0,74 \\
2009 & 72.45 & 0,64 \\
2010 & 71.76 & $-0,95$ \\
2011 & 72.27 & 0,71 \\
2012 & 73.29 & 1,41 \\
2013 & 72.78 & $-0,69$ \\
2014 & 70.82 & $-2,69$ \\
2015 & 70.23 & $-0,83$ \\
2016 & 69.62 & $-0,86$ \\
2017 & 69.99 & 0,53 \\
\hline Rata-rata & $\mathbf{7 5 , 2 5}$ & $\mathbf{0 , 1 1}$ \\
\hline
\end{tabular}

Sumber: Badan Pusat Statistik Provinsi Jambi, 2019(diolah)

\section{Perkembangan tingkat partisipasi angkatan kerja di Provinsi Jambi}

Tingkat partisipasi angkatan kerja di Provinsi Jambi merupakan perbandingan antara jumlah angkatan kerja dengan jumlah penduduk usia kerja yang ada di Provinsi Jambi. Tingkat partisipasi angkatan kerja dapat digunakan sebagai indikator tingkat kesulitan angkatan kerja untuk mendapatkan pekerjaan. Angka Tingkat Partisipasi Angkatan Kerja yang rendah menunjukkan kecilnya kesempatan kerja yang tersedia bagi penduduk usia kerja. Sebaliknya, angka Tingkat Partisipasi Angkatan Kerja yang tinggi menunjukkan besarnya kesempatan kerja yang tersedia. Tingkat Partisipasi Angkatan Kerja di Provinsi Jambi mengalami kenaikan dan penurunan selama kurun waktu 16 tahun terakhir yakni tahun 2002 hingga 2017. Tingkat Partisipasi Angkatan Kerja Provinsi Jambi dapat dilihat pada tabel dibawah ini.

Berdasarkan Tabel 4 diatas, menggambarkan perkembangan Tingkat Partisipasi Angkatan Kerja yang terjadi di Provinsi Jambi tahun 2002 hingga 2017. angka Tingkat Partisipasi Angkatan Kerja tertinggi terjadi pada tahun 2005 yaitu sebesar 68.69 persen dan terendah terjadi ditahun 2013 sebesar 64.65 persen, dan perkembangan tertinggi yang di capai dari tahun 2002 hingga 2017 yaitu terjadi di tahun 2005 yang diduga bahwa kenaikan TPAK terjadi karena bertambahnya jumlah angkatan kerja ditahun tersebut yang diikuti juga dengan bertambahnya laju pertumbuhan penduduk, dengan perkembangan Tingkat Partisipasi Angkatan Kerja sebesar 2.14 persen. Sedangkan TPAK terendah yaitu sebesar -5.20 persen pada tahun 2012, dan diduga dikarenakan penurunan angkatan pada tahun tersebut. Meningkatnya Tingkat Partisipasi Angkatan Kerja Provinsi Jambi secara perlahan menunjukkan kenaikan dari sisi pasokan (supply) tenaga kerja di Provinsi Jambi. 
Tabel 4. Perkembangan tingkat partisipasi angkatan kerja Provinsi Jambi

\begin{tabular}{ccc}
\hline Tahun & Tingkat Partisipasi AngkatanKerja & Perkembangan(\%) \\
\hline 2002 & 68.00 & - \\
2003 & 67.91 & -0.13 \\
2004 & 67.25 & -0.97 \\
2005 & 68.69 & 2.14 \\
2006 & 65.26 & -4.45 \\
2007 & 65.18 & 0.12 \\
2008 & 65.95 & 1.18 \\
2009 & 66.65 & 1.06 \\
2010 & 67.38 & 1.09 \\
2011 & 68.67 & 1.91 \\
2012 & 65.07 & -5.20 \\
2013 & 64.65 & -0.64 \\
2014 & 65.59 & 1.45 \\
2015 & 66.14 & 0,84 \\
2016 & 67.54 & 2.12 \\
2017 & 67.52 & -0.02 \\
\hline Rata-rata & $\mathbf{6 6 , 7 1}$ & $\mathbf{0 . 0 3}$ \\
\hline
\end{tabular}

Sumber: Badan Pusat Statistik Provinsi Jambi,2019(diolah)

Pengaruh upah minimum Provinsi, kemiskinan dan indek pembangunan manusia terhadap tingkat partisipasi angkatan kerja Provinsi Jambi

Hasil regresi dalam penelitian ini ialah untuk mengetahui pengaruh variabel Jumlah Penduduk, Upah Minimum Provinsi, Kemiskinan Dan Indeks Pembangunan Manusia terhadap tingkat Partisipasi Angkatan Kerja Di Provinsi Jambi. hasil penelitian diperoleh dari analisis regresi linear berganda yang diolah dengan bantuan aplikasi eviews9 berdasarkan data-data yang diperoleh sebanyak 16 tahun data penelitian. Untuk memperkecil variasi maka dapat diketahui Tingkat Partisipasi Angkatan Kerja sebagai variabel dependent dilambangkan dengan TPAK dan Upah Minimum (UMP), Tingkat Kemiskinan (TKM) dan Indeks Pembangunan Manusia (IPM) sebagai variabel independent. Untuk mengetahui bagaimana pengaruh variabel independent terhadap variabel dependent dapat dilakukan estimasi sebagai berikut:

Tabel 5. Hasil regresi

\begin{tabular}{lrllr}
\hline \multicolumn{1}{c}{ Variable } & Coefficient & Std. Error & t-Statistic & Prob. \\
\hline C & 165.0979 & 39.05266 & 4.227571 & 0.0012 \\
UMP & $-2.66 \mathrm{E}-06$ & $1.40 \mathrm{E}-06$ & -1.892658 & 0.0828 \\
TKM & -0.855881 & 0.494183 & -1.731913 & 0.1089 \\
IPM & -1.228333 & 0.471920 & -2.602843 & 0.0231 \\
\hline \hline R-squared & 0.516537 & Mean dependent var & 66.71563 \\
Adjusted R- & & & \\
squared & 0.270671 & S.D. dependent var & 1.328864 \\
S.E. of regression & 1.134860 & Akaike info criterion & 3.303213 \\
Sum squared resid & 15.45488 & Schwarz criterion & 3.496360 \\
& & & 3.313104 \\
Log likelihood & -22.42570 & Hannan-Quinn criter. & 1.636583 \\
F-statistic & 2.855621 & Durbin-Watson stat & \\
Prob(F-statistic) & 0.081605 & & \\
\hline Sumber $:$ Data diolah & 2019 & &
\end{tabular}

Sumber : Data diolah, 2019 
Dimana persamaannya adalah:

$$
\text { TPAK }=\beta_{\circ}+\beta_{1} \mathbf{U M P}_{1}+\beta_{2} \text { TKM }_{2}+\beta_{3} \text { IPM }_{3}+\mathbf{e}
$$

Dari hasil analisis yang digunakan dalam regresi linear berganda maka diperoleh hasil yang ditulis dalam bentuk persamaan sebagai berikut:

TPAK $=165.0979+-2.66 \mathrm{E}-06 \mathrm{UMP}+-0.855881 \mathrm{TKM}+-1.228333 \mathrm{IPM}$
$(0.828)$
(0.1089)
(0.231)

\section{Hasil uji statistik}

\section{Uji F statistik}

Uji F statistik dilakukan untuk melihat pengaruh signifikansi variabel independen yaitu Upah Minimum (UMP), Tingkat Kemiskinan (TKM) dan Indeks Pembangunan Manusia (IPM) terhadap variabel dependen yaitu Tingkat Partisipasi Angkatan Kerja (TPAK) di Provinsi jambi. Berdasarkan hasil regresi hasil Uji $\mathrm{F}$ dengan nilai prob. $\mathrm{F}$ statistik sebesar 0.081605 lebih kecil dari tingkat signifikan 0,10 sehingga dapat disimpulkan bahwa model regresi yang diestimasi layak digunakan untuk menjelaskan pengaruh Jumlah Penduduk, Upah Minimum, Tingkat Kemiskinan dan IPM terhadap Tingkat Partisipasi Angkatan Kerja di Provinsi jambi selama periode 2002-2017.

\section{Uji t statistik}

Uji t digunakan untuk menentukan apakah variabel-variabel independen dalam persamaan regresi secara individu berpengaruh signifikan terhadap variabel dependen. Pengujian ini dilakukan dengan membandingkan probabilitas t-hitung terhadap tingkat $\alpha$ $(10 \%$ atau 0,10$)$, dengan kriteria pengujian jika probabilitas t-hitung $>\alpha(0,10)$ maka pengaruh variabel independen itu tidak signifikan, sehingga Ho diterima, yang artinya variabel independen tidak berpengaruh secara individual terhadap variabel dependen. Sebaliknya jika probabilita t-hitung $<\alpha(0,10)$ maka pengaruhnya signifikan, sehingga Ha diterima, yang artinya variabel independen dapat mempengaruhi individual variabel dependennya.

Tabel 6. Rangkuman pengujian secara parsial uji t statistik

\begin{tabular}{ccccc}
\hline Variabel & t-hitung & Probabilitas & $\boldsymbol{A}$ & Keterangan \\
\hline UMP & -2.303829 & 0.0828 & 0.10 & Signifikan \\
TKM & -1.489233 & 0.1089 & 0.10 & Tidak Signifikan \\
IPM & -2.925112 & 0.0231 & 0.10 & Signifikan \\
\hline
\end{tabular}

Sumber : Data diolah, 2019

Berdasarkan hasil estimasi linear berganda, dapat diketahui pengaruh masingmasing variabel UMP, TKM dan IPM terhadap TPAK. Upah Minimum Provinsi (UMP). Hasil estimasi menunjukkan bahwa nilai prob. t-hitung UMP sebesar 0.0828 lebih kecil dari 0,10 sehingga dapat disimpulkan variabel UMP berpengaruh signifikan terhadap variabel terikat TPAK.

\section{Tingkat kemiskinan (TKM)}

Hasil estimasi menunjukkan bahwa nilai prob. t-hitung TKM sebesar 0.1089 lebih besar dari 0,10 sehingga dapat disimpulkan variabel TKM tidak berpengaruh signifikan terhadap variabel terikat TPAK. 


\section{Indeks pembangunan manusia (IPM)}

Hasil estimasi menunjukkan bahwa nilai prob. t-hitung IPM sebesar 0.0231 lebih kecil dari 0,10 sehingga dapat disimpulkan variabel IPM berpengaruh signifikan terhadap variabel terikat TPAK.

\section{Koefisien determinasi $\left(\mathbf{R}^{2}\right)$}

Koefisien Determinasi $\left(\mathrm{R}^{2}\right)$ dimaksudkan untuk mengetahui seberapa besar kontribusi variabel independent terhadap variabel dependent secara bersama-sama. Dari hasil pengolahan data diperoleh nilai koefisien determinasi $\left(\mathrm{R}^{2}\right)$ sebesar 0.516537 menunjukkan bahwa variabel-variabel independent (Jumlah Penduduk, Upah Minimum, Tingkat Kemiskinan Dan Indeks Pembangunan Manusia) secara bersamasama mampu menjelaskan perubahan pada variabel dependen ( Tingkat Partisipasi Angkatan Kerja) sebesar 51,65 persen. Variabel lain diluar model mampu menjelaskan perubahan variabel dependen hanya sebesar 48,34 persen.

\section{Hasil uji asumsi klasik}

\section{Uji normalitas}

Pengujian normalitas berfungsi untuk mengetahui apakah data pada penelitian ini bersifat normal atau tidak. Berdasarkan Gambar menunjukkan hasil uji normalitas dengan melihat nilai jarque-bera. Pada persamaan diperoleh hasil dari J-B hitung sebesar 1.666587 dengan probability 0.434615 . nilai probability J-B hitung sebesar $0.434615>0,10$ sehingga dapat disimpulkan bahwa residual terdistribusi normal yang artinya asumsi klasik tentang kenormalan terpenuhi.
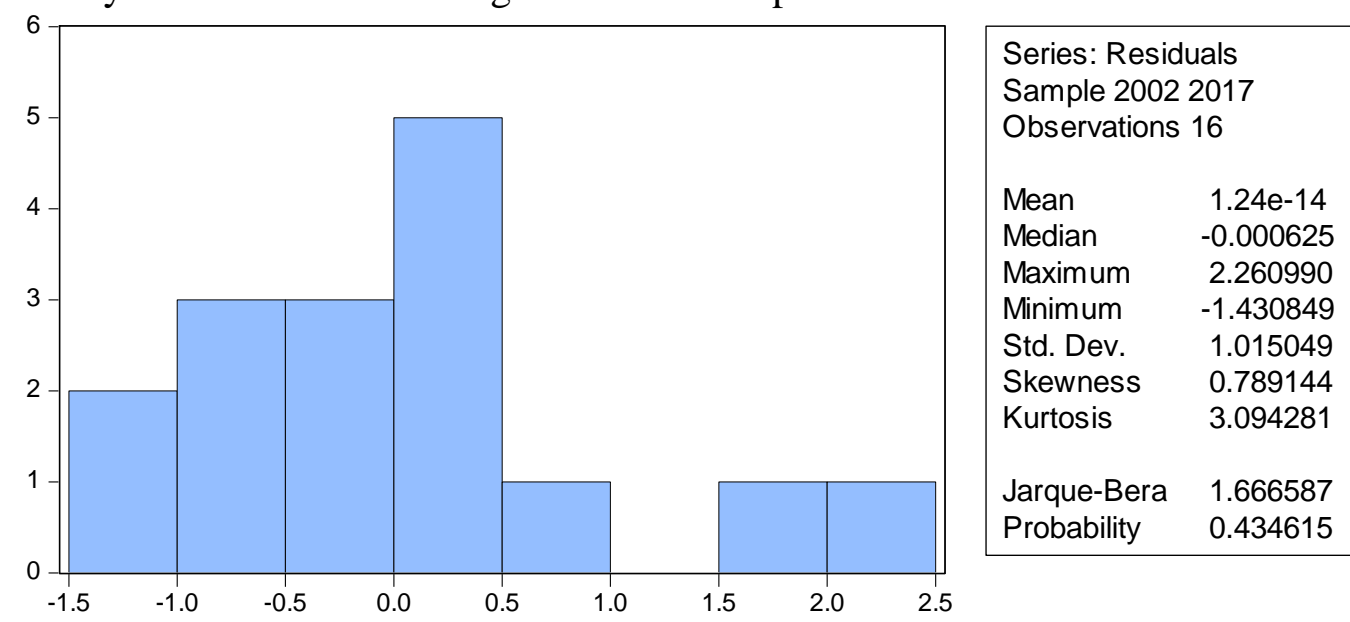

Sumber : Data diolah, 2019

Gambar 1. Uji normalitas

\section{Uji multikolinearitas}

Multikolinearitas adalah situasi dimana terdapat korelasi variabel bebas antara satu variabel dengan yang lainnya. Dalam hal ini dapat disebut variabel-variabel orthogonal. Variabel yang bersifat orthogonal variabel yang nilai korelasi antara sesamanya sama dengan nol.

Dari hasil uji multikolinearitas pada model dapat diketahui bahwa model tersebut lolos dari masalah multikolinearitas. Indikasi dapat dilihat dari nilai koefisien korelasi variabel upah minimum (UMP), Tingkat kemiskinan (TKM) dan indeks pembangunan 
manusia (IPM) yang lebih kecil dari 0,80. Dengan demikan dapat disimpulkan bahwa model tidak terdapat masalah multikolinearitas atau tidak mengandung korelasi yang tinggi antar variabel independen.

Tabel 7. Hasil uji multikolinearitas

\begin{tabular}{cccc}
\hline & UMP & TKM & IPM \\
\hline UMP & 1.000000 & -0.766824 & -0.016138 \\
TKM & -0.766824 & 1.000000 & -0.548853 \\
IPM & -0.016138 & -0.548853 & 1.000000 \\
\hline
\end{tabular}

Sumber : Data diolah, 2019

\section{Uji heteroskedastisitas}

Uji Heterokedastisitas dapat dilakukan dengan menggunakan Uji White, hasil Uji White pada persamaan adalah sebagai berikut :

Tabel 8. Hasil uji heteroskedastisitas

Heteroskedasticity Test: White

\begin{tabular}{llll}
\hline \hline F-statistic & 0.446370 & Prob. F(8,7) & 0.8595 \\
Obs*R-squared & 5.404932 & Prob. Chi-Square(8) & 0.7135 \\
Scaled explained SS & 3.183595 & Prob. Chi-Square(8) & 0.9223 \\
\hline \hline
\end{tabular}

Sumber : Data diolah, 2019

Keputusan terjadi atau tidaknya heteroskedastisitas pada model regresi linear adalah dengan melihat nilai prob. F hitung. Apabila nilai prob. F hitung lebih besar dari tingkat alpha 0,10 tidak terjadi heteroskedastisitas sedangkan jika nilai prob. F hitung lebih kecil dari alpha 0,10 maka artinya telah terjadi heteroskedastisitas. Nilai prob. F hitung sebesar 0.8595 yang berarti lebih besar dari alpha 0,10 sehingga tidak terjadi heteroskedastisitas.

\section{Uji autokorelasi}

Salah satu uji untuk mendeteksi autokorelasi adalah Breusch-Godfrey atau LM (Langrange Multiplier) test. Berikut adalah hasil uji autokorelasi :

Tabel 9. Hasil uji autokorelasi

Breusch-Godfrey Serial Correlation LM Test:

F-statistic

0.464493 Prob. $\mathrm{F}(2,10)$

Obs*R-squared

Sumber:Data diolah, 2019.

Dari hasil pengujian LM diketahui nilai prob F $(2,10)$ sebesar 0.6414 dapat juga disebut sebagai nilai probabilitas $\mathrm{F}$ hitung. Nilai prob $\mathrm{F}$ hitung lebih besar dari tingkat alpha 0,10 sehingga tidak terjadi autokorelasi. 


\section{KESIMPULAN DAN SARAN}

\section{Kesimpulan}

Perkembangan Upah minimum Provinsi Jambi setiap tahunnya selalu mengalami peningkatan dalam kurun waktu 16 tahun terakhir dari tahun 2002-2017 dengan rata-rata sebesar 14,10 persen, kemudian perkembangan Tingkat Kemiskinan dan Indeks pembangunan Manusia berfluktuasi dengan rata-rata Tingkat kemiskinan sebesar -2,98 persen dan IPM sebesar 0,11 persen. Tingkat Partisipasi Angkatan Kerja di Provinsi Jambi tahun 2002-2017 juga mengalami kenaikan dan penurunan. Dengan rata-rata Tingkat Partisipasi Angkatan Kerja selama kurun waktu 16 tahun terakhir sebesar 67,52 persen.

Dari hasi regresi menunjukkan Upah Minimum Provinsi Jambi dan Indeks Pembangunan Manusia berpengaruh signifikan terhadap Tingkat Partisipasi Angkatan Kerja di Provinsi Jambi. Sedangkan Tingkat Kemiskinan tidak berpengaruh sinifikan terhadap Tingkat Partisipasi Angkatan Kerja di Provinsi Jambi. Dan secara bersamasama variabel-variabel bebas yaitu UMP, Tingkat Kemiskinan dan IPM berpengaruh signifikan terhadap Tingkat Partisipasi Angkatan Kerja.

\section{Saran}

Pemerintah diharapkan dapat meningkatkan kualitas dan skill sumber daya manusia agar para pencari kerja dapat bersaing dalam pasar tenaga kerja, agar dapat memperbanyak pilihan dalam memilih pekerjaan yang diinginkan dan pemerintah juga diharapkan dapat memperluas lapangan pekerjaan agar para pencari kerja mendapatkan pendapatan yang dapat memenuhi kebutuhan dan dapat mensejahtrakan.

Perkembangan jumlah penduduk harus sejalan dengan perluasan lapangan pekerjaan, Maka pemerintah harus mengambil kebijakan untuk mengatasi masalah kependudukan agar laju pertumbuhan penduduk sejalan dengan lapangan pekerjaan yang ada. Kemudian Tingkat Kemiskinan dan IPM juga berpengaruh negatif dan signifikan terhadap Tingkat Partisipasi Angkatan Kerja maka diperlukan kebijakan pemerintah dalam membenahi kualitas SDM agar kualitas SDM Provinsi Jambi dapat bersaing di pasar tenaga kerja.

\section{DAFTAR PUSTAKA}

Arsyad, Lincolin.(1999). Pengantar perencanaan dan pembangunan ekonomi daerah. BPFE: Yogyakarta.

Arsyad, Lincolin.(2004). Ekonomi pembangunan edisi ke-empat. SekolahTinggi Ilmu Ekonomi YKPN: Yogyakarta.

Badan Pusat Statistik Provinsi Jambi. (2019). Data kemiskinan 2002-2017, dalam https://jambi.bps.go.id di akses akses Tanggal 27 agustus 2019. Pukul 12.30

Badan Pusat Statistik Provinsi Jambi. (2019). Indeks Pembangunan Pembangunan Manusia (IPM) Provinsi Jambi 2002-2017, dalam https://jambi.bps.go.id di akses tanggal 27 Agustus 2019. Pukul 12.30

Badan Pusat Statistik Provinsi Jambi. (2019). Upah minimum provinsi, dalam https://jambi.bps.go.id di akses Tanggal 27 Agustus 2019. Pukul 12.30

Badan Pusat Statistik Provinsi Jambi.(2019). Tingkat partisipasi angkatan kerja, dalam https://jambi.bps.go.id di akses Tanggal 27 Agustus 2019, Pukul 12.30

Depnakertrans.(2004). Standar kompetisi kerja nasional Indonesia. Depnakertrans: Jakarta 
Ghozali, Imam.(2005). Aplikasi analisis multivariate dengan SPSS. Badan UNDIP: Semarang.

Ghozali, Imam.(2012). Aplikasi analisis multivariate dengan program IBM SPSS. UNDIP: Semarang.

S Rahmadi, P Parmadi. (2019). Pengaruh ketimpangan pendapatan dan kemiskinan terhadap pertumbuhan ekonomi antar pulau di Indonesia, Jurnal Paradigma Ekonomika 14 (2), 55-66

Sumodiningrat.(2001). Pengantar statistika. Andi: Jakarta.

Z Ziyadaturrofiqoh, Z Zulfanetti, M Safri. (2018). Pengaruh PDRB, upah minimum provinsi dan pengeluaran pemerintah terhadap penyerapan tenaga kerja di provinsi jambi, E-Jurnal Ekonomi Sumberdaya dan Lingkungan 7 (1), 13-22 